\title{
МИСТЕЦТВОЗНАВСТВО
}

DOI: https://doi.org/10.32839/2304-5809/2021-5-93-49

УДК 7.071.3(477)"19"Шолдра

Андрес Г.О.' ${ }^{1}$ Порплиця В.В. ${ }^{2}$

Національна академія образотворчого мистецтва та архітектури

\section{ТВОРЧІСТЬ ДІОНІЗІЯ ШОЛДРИ ТА ЙОГО ДІЯЛЬНІСТЬ У РЕСТАВРАЦІЙНІЙ МАЙСТЕРНІ ТЕРНОПІЛЬСЬКОГО ОБЛАСНОГО ХУДОЖНЬОГО МУЗЕЮ}

\begin{abstract}
Анотація. Стаття присвячена дослідженню творчості тернопільського художника та реставратора Діонізія Шолдри. Мета - дослідити та проаналізувати творчий доробок художника та його реставраційну діяльність в Тернопільському обласному художньому музеї в якій він працював. У статті розглянута творчість художника та реставратора, а також його вплив на реставращійну діяльність в Тернопільському обласному художньому музеї. Для цього здійснено мистецтвознавчий аналіз полотен художника, проаналізовано його реставраційну діяльність, також висвітлено біографію митця, яка я важливим фрактором розуміння становлення Шолдри як художника та реставратора.
\end{abstract}

Ключові слова: художник, реставрація, тернопільські художники, художники-емігранти, Діонізій Шолдра.

Andres Anna, Porplytsia Victoria National Academy of Fine Art and Architecture

\section{CREATIVITY OF DIONIZIY SHOLDRA AND HIS ACTIVITIES IN THE RESTORATION WORKSHOP OF THE TERNOPIL REGIONAL ART MUSEUM}

Summary. The article is devoted to the study of the works of Ternopil artist and restorer - Dioniziy Sholdra. The aim is to research and analyze the artist's creative work and his restoration activities in the Ternopil Regional Art Museum where he worked. The article considers the work of the artist and restorer, as well as his influence on the restoration activities in the Ternopil Regional Art Museum. For this purpose, an art analysis of the artist's paintings was performed, his restoration activities were analyzed, and the biography of the artist was covered, which is an important factor in understanding Sholdra's development as an artist and restorer. Creativity and restoration of Dioniziy Sholdra is a valuable asset for Ukrainian culture. The artist is an extraordinary master of his craft, opening a restoration studio in New York, which was entrusted to the works of Pablo Picasso and Salvador Dali. Sholdra worked very actively in the artistic environment of the Ukrainian diaspora, which contributed to the development of a new creative generation of Ukrainians outside the homeland. And having reached certain heights abroad, the artist came to his hometown of Ternopil to pass on his invaluable experience and knowledge. Dioniziy Sholdra - started restoration work at the Ternopil Regional Art Museum, as well as restored and conserved a dozen works of Western European painting, which made a significant contribution to the preservation of Ukraine's cultural heritage. Although the artist was already of respectable age, he restored for the museum works from the art collection, which are the pearls of the museum's collection, namely: a portrait of "Singer" by Megoffer, "Portrait of an Old Woman" by V. Makovsky, an icon of the unknown master "Jesus Christ (Holy Eucharist)", "God the Father with the saints" is also an unknown master, but in general in his creative work dozens of restored paintings. Dionysius also acted as a mentor. He passed on his skills to Ivan Kuzyk. Thus, the direction of restoration in the museum has undergone further development. Despite the fact that the artist's creative heritage is underestimated in Ukraine today, there is also no thorough work on the life, work and restoration activities of the Ternopil artist. It is the absence of art works about the work of Dioniziy Sholdra that determines the relevance of the topic.

Keywords: artist, restoration, Ternopil artists, emigrant artists, Dioniziy Sholdra.

Постановка проблеми. Художня i pecтавраційна діяльність Діонізія Шолдри є цінним внеском для всієї культурної спадщини України. Майстерність Діонізія підтверджуе праця 3 роботами майстрів світового рівня. Як зазначає I. Дуда в статті «Маляр неба і самітніх дерев», художнику доводилося реставрувати пастель П. Пікассо і картини С. Далі. Шолдра активно працював у мистецькому середовищі української діаспори, чим посприяв розвитку нового творчого покоління українців за межами батьківщини. А досягнувши певних висот за кордоном, художник приїхав у його рідне місто Тернопіль, щоб передати накопичений життям досвід. Діонізій Шолдра - започаткував реставращійну діяльність в Тернопільському обласному художньому музеї, а також реставрував та провів консервацію десятка творів західно-європейського мистецтва, чим зробив вагомий внесок у збереження культурної спадщини України. Попри те, творча спадщина художника сьогодні $є$ недооціненою в Україні, також грунтовної праці про життевий шлях, творчість та реставраційну діяльність тернопільського художника немає. Саме відсутністю мистецтвознавчих пращь про творчість Діонізія Шолдри визначається актуальність теми. 
Аналіз останніх досліджень і публікацій. Джерельна база дослідження складаеться, переважно, зі статей, присвячених творчості та біографіï Діонізія Шолдри, надрукованих у періодичних виданнях, а також інтерв'ю, взятих авторами у нього. Переважна більшість статей про Діонізія Шолдру мае здебільшого індормативний характер, тож особливого значення набуває каталог виставки 1995 року Тернопільського обласного художнього музею про Діонізія Шолдри, написаний директором музею Ігорем Дудою, який особисто працював із митцем.

Додотичнихджерелналежитьбібліографічний покажчик «Мистці Тернопільщини. Частина 1. Образотворче мистецтво», у якому про творчість та біографрію Діонізія Шолдри наводяться лише загальні фракти; стаття А. Золотнюк «Діонізій Шолдра: «Мене зробила природа і праця»" та ряд інших публікацій. До важливих допоміжних інформативних джерел належать каталоги персональних, групових виставок; відгуки і рецензії на них.

Мета статті - дослідити та проаналізувати творчий доробок художника, його реставраційну діяльність у Тернопільському обласному художньому музеї.

Виклад основного матеріалу. Діонізій Шолдра - гордість Тернополя, не тільки знаний майстер живопису але й чудовий реставратор, який започаткував реставраційну діяльність в Тернопільському обласному художньому музеї (далі ТОХM), а також відреставрував для музею твори із художнього фонду, що становлять перлини колекції музею, а саме: портрет «Співачка» Ю. Мегоффера, «Портрет старої» В. Маковського, ікону невідомого майстра «Ісус Христос (Св. Євхаристія)», «Бог-Отець із святими» також невідомого майстра, але загалом в його творчому доробку десятки відреставрованих картин, які тепер експонуються у меморіальній залі Діонізія Шолдри в ТOXM.

Творчість Д. Шолдри є більш відомою за межами України, адже він один із яскравих представників української діаспори, яка у свій час активно розвивалася в Америщі. Плідно працюючи Шолдра заслужив визнання та відкрив власне ателье в Нью-Йорку в якому йому доводилося реставрувати пастель П. Пікассо і картини С. Далі, з яким був особисто знайомий.

I хоча практичні навички в реставрації, давали йому незалежність але вся його творчість демонструе тугу за батьківщиною. Думки про рідний край не полишали його, тому згодом Діонізій повернувся в Україну щоб творити та ділитися здобутим досвідом.

Мала батьківщина Діонізія Михайла Шолдри - місто Тернопіль, в якому він народився 16 жовтня 1925 року. Будинок де художник провів свое дитинство зберігся до нашого часу на вулиці Листопадовій, 8, на якому у 1998 році встановлено пам'ятний знак Діонізію Шолдрі скульптором Олександром Маляром. Упродовж 1932-1944 років Діонізій навчався в Тернопільській гімназії імені Юліуша Словацького в якій викладали малювання. Більше того в експозиції ТОХМ зберігаеться копія атестату із шостого класу, де зазначаеться, що з малювання в Шолдри було «добре». 3 того часу (1943р.) залишився рисунок олівцем Надставної церкви. Першими враженнями дитинства, як зазначив директор TOXM Ігор Дуда, були: блакитна гладінь ставу, захід сонця над Галя-горою, прозорість неба, які привели його до розуміння плинності життя і вічності природи. Але щоб повернутися знову до цього розуміння йому треба було прожити непросте життя наповнене тривогами, нестатками i щоденною працею. «Якщо я сьогодні є мистцем, - каже маляр, - то його з мене зробила природа, праця, любов до праці. В житті мені прийшлося дуже тяжко: я не мав тата, мами, брата, свата...» [2, с. 3].

Згодом, 8 березня 1944 року митець виїхав до Австрії, де впродовж 1945-1950 років перебував у таборі для переміщених осіб у м. Ландек (Тироль, Австрія). Побутує думка, про те що художник виїхав під час подій «золотого вересня». «За два тижні до “золотого вересня", дізнавшись, що його прізвище - у списках на знищення, Діонізій з родиною встиг виїхати з України» [Маляр неба і самітніх дерев, TV4], але ймовірно, що це не так, тому що зазначені події відбувалися 1939-1941, а художник із сім'єю виїхав в 1944 році.

Перебуваючи в Австрії митець навчався в університеті Інсбрука, який заснований ще в 1669 році. Там він вивчав мистецтво, історію мистецтва і теорію реставрації у професора Отто фон Луттеротті, який походить 3 тирольської шляхетної родини Лутротті, а повне його ім'я Отто Луттуротті, лицар Газоліса і Лангенталя. Професор був австрійським істориком мистецтва і також вивчав історію мистецтва в Інсбруку та Відні.

Далі з'ясовуемо, що в червні 1950 року митець мігруе до Сполучених Штатів Америки. А в 1952 році вступае до Об'єднання Митців Українців в Америці (далі - ОМУА), організація заснована в тому ж році, коли вступив до неї Діонізій, також ОМУА сприяла всілякому творчому розвитку українських митців в США. Вже через 5 років (у 1957 р.) художник переїжджае в Європу і перебувае в Парижі. У тому ж році він повернувся в Інсбрук. В Шолдри була жага до знань, тому він продовжив художні студії і практичну реставрацію у Віденській академії мистецтв у проф. Айгенберга, Валізера впродовж 1958-1965 pр. Академія заснована ще в 1692 році, іiі закінчували не тільки відомі іноземні студенти, але й добре відомі наші співвітчизники, наприклад, засновник самобутньої школи українського мистецтва Михайло Бойчук, поет, літературознавець, критик та художник Богдан Лепкий, а також майстер історичної картини Микола Івасюк та інші художники.

Отримавши певні знання та напрацювавши досвід, в червні 1965 року Діонізій повертаеться у США і влаштовуеться в реставраційну фірму Ю. Леви в Нью-Йорку. А вже у вересні того ж року відправляеться в місто Лейтбрідж, Канада. Взагалі, можемо прослідкувати, що митець доволі часто подорожував, ймовірно він черпав із цього натхнення для творчості. Перебуваючи в Канаді, через кілька місяців після приїзду митець організовуе індивідуальну виставку в Лейтбріджі. Надалі він брав участь у річних виставках ОМУА: третя мистецька виставка 1955 - «Краєвид», «Осінь» де Діонізій Шолдра 
представив роботи олією; четверта мистецька виставка 1956 року - «Перед бурею», «Осінь»; п’ята мистецька виставка 1957 «Буревій», «Потік»; сьома 1960 року - «Над озером» і «Дерево»; восьма 1961 - «Після дощу» , «Буревій»; дев’ята 1962 "Два дерева», "Самота». Ще одну роботу «Життя і смерть» 1964 р. можемо побачити в унікальному україномовному виданні "Нотатки з мистецтва» № 15, 1975 р., репродукція чорно-біла, тому не можна відчути кольорову гамму але на контрасті темного тла яскраво виділяеться людське обличчя із пронизливим поглядом. А звертаючи на деталі можна зазначити, що робота $є$ доволі символічною. Ігор Дуда стверджуе, що: «В 1980-их починає домінувати мотив високого неба і поламаних самітніх дерев, палітра світлішає, кольорова гамма збагачується, а техніка накладення фарби шпаклею (мастихіном) надає рельєфності деревам і землі» [2, с. 3], але звертаючи увагу, на те, які роботи представлені на дев'ятій мистецькій виставці в 1962, можемо прослідкувати, що мотив самотності з'являеться ще в 60-х роках.

Діонізій Шолдра брав участь у виставках разом із такими відомими майстрами як П. Андрусів, С. Борачок, Я. Гніздовський, С. Гординський, Д. Горняткевич, Е. Козак, Ї. Кучмак, В. Ласовський, А. Малюца, Л. Молодожанин, М. Мороз, М. Осінчук, Б. Титла, П. Холодний, саме такий перелік імен, половина з яких тернополяни, дає уяву про мистецьке еміграційне середовище, в якому перебував Д. Шолдра.

Через десять років після того як художник повернувся в США його чекало не аби яке досягнення, він відкриває власне реставраційне ательє в Нью-Йорку на розі 45 Стріт і 5 Авеню. В ателье він повертав до життя мистецькі твори із приватних збірок та мав постійних клієнтів. Вражаючим $є$ те, що йому на реставрацію приносив свої картини Сальвадор Далі, також йому доводилося реставрувати пастель Пабло Пікассо «Той сам забирав картину з реставращії. Далі подивився на неї, заплатив, і попросив картонку - буквально за кілька хвилин намалював корону іспанської імперії. До речі, про Далі казав, що не бачив людини простішої у спілкуванні» [4].

Активна робота реставратора припинилася раптово, в 1982 році з невідомих причин загорівся будинок, сьомий поверх якого займало ателье. Художник врятувався чудом але при цьму пошкодив ногу. Трагічнну подію описала в двох номерах газета «Нью-Йрк Пост» [2, с. 8]. На превеликий жаль, майже весь творчий доробок Д. Шолдри згорів у палаючому будинку, збереглися тільки два образи - «Люба» (Портрет дочки) і натюрморт фрранцузького митця Б. Нуовілля, яку згодом він реставрував. Ці події залишили слід у творчості автора надалі. Можливо, саме після ціеї події, основним мотивом в творчості Діонізія Шолдри стало самотне дерево, дерево на межі життя і смерті.

Датування свідчить, що темний фоон властивий, за окремими винятками, для творів $1950-$ початку 60-их років («Процесія», «Втікачі», «Портрет Гайді») - часу пошуків і становлення [3].

На картині «Процесія» ми можемо побачити групу людей, які рухаються в одному напрямку. Картина витримана в темних, холодних тонах, люди зображенні без лиця, що дуже підсилює едект напруги, смутку i таємничості. Робота створена в 1964 році, виконана олією на полотні і зараз зберігається у ТОХМ.

На картині «Втікачі», що створена того ж року, зображено двоє чоловіків. Їхні обличчя на темному тлі ледь освітлюе тепле світло. На полотні також зроблено акцент на двох чарках, які розташовані в правому нижньому кутку. Хоч і обличчя виконані доволі примітивно, у очах втікачів можна побачити розпач, відчай, певну пустоту і можливо навіть злобу. Ще одна робота створена в 1964 рощі «Дороговказ» витримана в темних кольорах. Холодне, безкрайне небо на заході сонця та хвилі, які піднімае вітер. Саме тому воду художник відобразив пастозно. Також передній план митець виділив пастозно із контрастом світла і тіні, зробивши акцент на дороговказ.

Ще одна робота із раннього періоду творчості «Жінка з дитиною» 1951 року, виконана олією на полотні. На темному фоні зображена жінка 3 дитиною на руках, що віддалено нагадуе образ «Мадонни». Жінку і дитину освічуе тепле світло, що м'яко і гладко лягає на їхні обличчя, створюючи певні рефлекси. Молода та приваблива жінка ошатно одягнена в яскраво червоний одяг iз великим червоним капелюхом та золотими сережками, що виблискують на світлі. Дитина дещо нахилила голову і притуляється до жінки. İх погляд зосереджений. Очі художник зобразив великими, як у жінки, так і у дитини, ймовірно прагнучи передати певний внутрішній стан. В міміці жінки дещо вловлюеться здивування і задуманість, а в дитини цікавість та допитливість. Митець вдало працюе із світлотінню, обличчя ж виконані у примітивній манері.

Загалом усім вищезазначеним роботам 1950-початку 60-их років притаманне темне тло, напруга, певна таємничість та загадковість, ми можемо сміло говорити, що це дійсно час пошуку та становлення Діонізія Шолдри як митця, адже в ці роки художник емігрував до США і мабуть саме це викликало у нього певні емоції смутку та туги за рідним домом. Також в 60-их він продовжував студії малярства та практичну реставрацію у Віденській Академії Мистецтв, що ймовірно підштовхнуло його до нових пошуків та фором.

Варто зазначити, що Шолдра був секретарем редакційної колегії, яка підготувала до друку грунтовну працю - «Книгу творчості Українських Мистщів поза Батьківщиною», видану у Філадельфї 1981 року. У редакщійну колегію також входили: український скульптор-монументаліст, голова ОМУА Михайло Черешньовський, український маляр-монументаліст сакрального мистецтв, графрік Михайло Дмитренко, графік і живописець Василь Дорошенко, графрік, майстер офорта Яків Гніздовський та інші.

Незважаючи на нищівну пожежу вже через рік митець організовує індивідуальну виставку в галереї ОМУА в Нью-Йорку. 3 ціеї нагоди Іван Кедрин-Рудницький в статті «Діонізій Шолдра сумні дерева і веселе небо» писав: «...Це не аматор ані піваматор, а мистець високої кляси з фраховою освітою таким своєрідним стилем, який ставить його у перших рядах сучасних мистців середущої генерації» [2, с. 5].

У 1983 році художник створив прекрасну роботу «Самітнє дерево. Туга». Дерево зображене дуже 
пастозно, в центрі полотна на передньому плані. На задньому плані безкрайне, високе небо, яке загорнуте у темні хмари, які ближче до горизонту стають майже чорними. Складається враження, що це самотне дерево знаходиться на самісінькій вершині гори, де ще пастозно лежить сніг.

Діонізій Шолдра - людина світу, багато подорожував, знав п'ять мов, але повторював: “Де б я не був, які гроші не мав в кишені, якою мовою не говорив. Та, як лягав спати, думав тільки українською. I думав, що ще повернуся» [4]. I ось в 1991 році він вперше від часу еміграції відвідує Тернопіль, а через два роки повертається назавжди. Художник не міг уявити собі кращого місця як Тернопіль, про це ми дізнаємось у книзі тернопільського журналіста «Листи до друга», де він зазначає: "...Стрункий, сивий і такий на вигляд молодий чоловік. Очі світяться енергією і доброзичливістю... Пан Діонізій Шолдра, саме так звати мого іспанського гостя, жваво жестикулює, сміється і зітхає, радіє і обурюеться. Усі ці емоціі викликає в нього Підзамче, точніше, спогади про цей куточок Тернополя, що містився між замком і Надставною церквою... Ах, Підзамче. Я марив про нього за океаном... Здається, там і мама ще жива. I просить, аби побіг я на ринок за чимось. I друзі мене там чекають - здавалось... Але все спливло з водою, з роками...» [2, с. 6]. Звертаючи увагу на такі цитати, ми відразу знаходимо причину основного мотиву самотності у творчості художника.

У 1994 році із Нью-Йорка в Київ привезено 52 картини Шолдри, які експонувалися в «Золотому залі» Українського фонду культур. Згодом роботи були подаровані самостійній Україні в особі TOXM.

Кар'єра реставратора продовжилася в Тернополі, коли він очолив реставращійну майстерню TOXМ в 1993 рощі. Як зазначав Ігор Дуда, спеціалістів такого профілю в місті ніколи не було. Д. Шолдра ознайомився з методами консервації та реставрації в Національному музеї у Львові, Українському науково-дослідному реставраційному центрі в Киеві і прийшов до сумного висновку, що цей досвід далекий від світового рівня. За короткий час він реставрував картини «Співачка» Ю. Мегофрфера і «Портрет старої» В. Маковського, провів консервацію десятка творів західно-европейського малярства, що сьогодні знаходяться в постійній експозиції музею. Роботи виконував власними інструментами і матеріалами привезеними з Америки та Іспанії. Мав намір створити у Тернополі школу реставраторів, передати знання, фрахові таємниці і накопичений практичний досвід молодому поколінню українських реставраторів. Через ряд об'єктивних причин цей план не вдалося здійснити [2, с. 6].

Високу професійність майстра підкреслюе також переконання, що невдала реставрація приносить більше шкоди твору, ніж користі і т.зв. «врятовані шедеври» будуть назавжди втрачені. Це підтверджуеться основними правилами реставраторів: «Реставрація закінчуеться там, де починається франтазія», «Сумніваєшся - не роби» i «Якщо можна не робити реставрацію - не роби». Лише обережне втручання в авторський матеріал і використання всіх можливих засобів консервації та збереження оригіналу дає можливість повернути експозиційний вигляд навіть дуже пошкодженим творам [1].

Реставраційній діяльності в ТОХМ поклав початок Діонізій Шолдра, реставрувавши першим у грудні 1993 - січні 1994 р. портрет "Співачка» Ю. Мегофрdpepa, чудового надбання польського майстра доби модерну. Потім Діонізій відновив «Портрет старої» В. Маковського. Також ікону невідомого майстра «Ісус Христос (Св. Свхаристія)» початку XX ст., процес реставрації до і після можна побачити у довіднику TOXМ за 1991-2011 рр. Надалі Шолдра відновлював «Бог-Отець із святими» невідомого майстра сер XIX ст., реставрацію останньої закінчував його учень Іван Кузик.

Діонізій Шолдра мав багато планів, але ці плани перервала нищівна карцинома, яка зупинила його життя в 1995 рощі. Хоча школу реставраторів митець і не відкрив, але започаткував діяльність реставраційної майстерні у ТОХМ, яка активно працюе і сьогодні. В різні роки діяльності TOXM в реставраційній майстерні працювали сім реставраторів включно із Д. Шолдрою, які повернули до життя 89 предметів станкового живопису та іконопису. Найбільше творів реставрувала Вікторія Демків - 48, вона працюе в музеї з 2003 року. Одними із тих, що відновила Вікторія - великоформатні картини невідомих авторів «Свята родина в Єрусалимському храмі» XVIII ст. та «Батьколюбима римлянка» XIX ст. Раніше вони зберігалися в галереях графрьких маєтків, а сьогодні $є$ надбаннями тернополян і широкого загалу [Врятовані скарби, Тернопільська обласна рада]. Випускники Львівської національної академії мистецтв, реставратори Юлія ДемковичСкаковська і Тарас Заєць реставрували 26 творів. Це ікони 3 храмів Тернопільщини, картини які надійшли 3 Коропецького палацу графра Бадені [Врятовані скарби, Тернопільська обласна рада]. Художники-реставратори Іван Кузик та Олена Карцева відновили вісім картин (п'ять із фондів музею, три - із збірки Почаївського історико-художнього музею) [Врятовані скарби, Тернопільська обласна рада]. Дві картини відреставрувала Свгенія Рудюк: «Портрет молодого чоловіка 3 пірначем» невідомого автора XVIII ст. і «Портрет жінки» Каміли Буковскої 1920-ті рр.

Музей також співпрацюе із іншими реставраційними центрами. «В останні роки музей налагодив співпрацю з Львівською фрілією Національного науково-дослідного реставраційного центру України (завідуючий Тарас Откович). Львівськими реставраторами було проведено ряд реставращійно-консерваційних заходів зі збереження перлини музейної колекції, дерев'яної скульптури невідомого автора «Розп'яття» (кін. XVII ст.). Пам'ятка була передана музею Митрополитом УАПЦ Мефодієм у 2007 р. Під дією шкідливих фракторів: вологи, грибків та шкідників, фрігура була суттево пошкоджена» [2]. Така співпраця сприяе розвитку реставраторів, обміну знаннями та досвідом і якнайбільш детальному вивченні пам'яток.

Висновки. Художня i реставраційна діяльність Діонізія Шолдри $є$ значним внеском не тільки для збереження творів мистецтва в Тернопільському обласному художньому музеї (далі TOXM), але й всієї культурної спадщини України. Діяльність Шолдри поклала початок реставра- 
ційній майстерні в ТОХМ, яка працюе і сьогодні, активно зберігаючи фондову колекщію музею.

Майстерність Діонізія підтверджуе праця з роботами майстрів світового рівня. Як зазначає I. Дуда в статті «Маляр неба і самітніх дерев», художнику доводилося реставрувати пастель П. Пікассо і картини С. Далі.

Митець хоча вже і був в поважному віці, відреставрував для музею твори із художнього фонду, що становлять перлини колекції музею, а саме: портрет «Співачка» Ю. Мегодрdера, «Портрет старої» В. Маковського, ікону невідомого майстра «Ісус Христос (Св. Свхаристія)», «БогОтець із святими» також невідомого майстра, але загалом в його творчому доробку десятки відреставрованих картин. Діонізій виступав і в ролі наставника. Свої вміння він передав Івану Кузику. Таким чином напрям реставрації в музеї зазнав свого подальшого розвитку.

Враховуючи значний внесок Шолдри як реставратора, його творчість як художника до кінця лишається недооціненою. Однак, прослідковуючи його біографічні дані, можна зрозуміти чому музейники, а саме директор TOXM I. Дуда, як дослідник творчості Шолдри називає його художником неба і самотніх поламаних дерев. В першу чергу, це пояснюеться нелегким життям в еміграції. I хоча практичні навички в реставрації, давали йому незалежність але вся його творчість демонструє тугу за батьківщиною. Особливо на Діонізія вплинула пожежа, що сталася в його майстерні. Внаслідок чого художник постраждав і згоріла велика кількість його робіт, які так і залишилися незафіксованими і невідомими. Всі ці події залишили слід у творчості автора.

В ТОХМ зберігається 16 робіт Діонізія Шолдри, проаналізованим творам 50-60-их рр. XX ст., притаманне темне тло, напруга, певна таємничість та загадковість, аналіз робіт дає нам право стверджувати, що це період пошуку митця. Дані роботи художник подарував музею і це єдиний творчий спадок митця в Україні.

Мотив самотності з'являеться ще в 60-х роках, підтвердженням чого є робота «Дороговказ» 1964 р., а в 1980-их починає домінувати мотив неба і дерев, палітра світлішає, кольорова гамма збагачується, а техніка накладення фрарби мастихіном надає рельерності деревам і землі, це можемо прослідкувати на роботі «Самітне дорево» 1983 р.

Хоч і не чисельні, але наявні в Україні зразки творчості і реставраційної діяльності Діонізія Шолдри є цінним надбанням для української культури.

Оглянувши багатогранність реставратора-художника Діонізія Шолдри і малу кількість досліджень з цієї тематики, ми можемо говорити про те, що ця постать заслуговуе своє місце в подальших грунтовних мистецтвознавчих дослідженнях.

\section{Список літератури:}

1. Врятовані скарби. Тернопільська обласна рада. 2019. URL: http://te-rada.org/list/?type=view\&id=9870 (дата звернення: 15.04.2021).

2. Діонізій Шолдра: Малярство : каталог виставки / автор упорядник Ігор Дуда. Тернопіль, 1995.

3. Зозуляк Є. 3 доріг життя: (Діонізій Шолдра). Вільне життя. Тернопіль, 1995. № 10.

4. Золотнюк А. Коли дерева тягнуться увись: [живописець Діонізій Шолдра]. Вільне життя. 2015. № 11. С. 6.

5. Маляр неба і самітніх дерев. Виставка до ювілею маляра Діонізія Шолдри. TV4. 2015. URL: https://tv4.te.ua/ malyar-neba-i-samitnih-derev-vystavka-do-yuvileyu-malyara-dioniziya-sholdry/ (дата звернення: 15.04.2021).

\section{References:}

1. Vrjatovani skarby [Rescued treasures] (2019) Ternopil's'ka oblasna rada [Ternopil Regional Council]. Available at: http://te-rada.org/list/?type=view\&id=9870

2. Igor Duda (1995) Dionizij Sholdra: Maljarstvo: katalog vystavky [Dionyziy Sholdra: Painting: exhibition catalog] Ternopil. (in Ukrainian)

3. Zozuljak (1995) Z dorig zhyttja: (Dionizij Sholdra) [From the roads of life: (Dionyziy Sholdra)]. Vil'ne zhyttja, vol. 10 , p. 7.

4. Zolotnjuk A. (2015) Koly dereva tjagnut'sja uvys': [zhyvopysec' Dionizij Sholdra] [When a tree stretches upwards: [painter Dionyziy Sholdra]. Vil'ne zhyttja, vol. 11, p. 6.

5. TV4 (2015) Maljar neba i samitnih derev. Vystavka do juvileju maljara Dionizija Sholdry [Painter of the sky and the trees themselves. Exhibition dedicated to the anniversary of the painter Dionyziy Sholdra]. Available at: https://tv4.te.ua/malyar-neba-i-samitnih-derev-vystavka-do-yuvileyu-malyara-dioniziya-sholdry/ 